\title{
Total and partial digestibility, rates of digestion obtained with rumen evacuation and microbial protein synthesis in bovines fed fresh or ensiled sugar cane and corn silage ${ }^{1}$
}

\author{
Gustavo Chamon de Castro Menezes ${ }^{2}$, Sebastião de Campos Valadares Filho ${ }^{3}$, Felipe \\ Antunes Magalhães ${ }^{4}$, Rilene Ferreira Diniz Valadares ${ }^{5}$, Lays Débora Mariz ${ }^{6}$, Edenio \\ Detmann $^{3}$, Odilon Gomes Pereira ${ }^{3}$, Maria Ignez Leão ${ }^{3}$
}

\footnotetext{
1 Projeto financiado pelo CNPq.

2 Doutorando em Zootecnia - UFV.

${ }^{3}$ Departamento de Zootecnia - UFV.

${ }^{4}$ Doutorando em Zootecnia - UFMG.

${ }^{5}$ Departamento de Veterinária - UFV.

${ }^{6}$ Mestranda em Zootecnia - UFV.
}

ABSTRACT - It was evaluated intake, rumen and intestinal digestibility and passage and digestion rates in bovines fed diets constituted of corn silage, crushed sugar cane and given fresh, crushed sugar cane and given after 72 hours of storage, ensiled sugar cane with $1 \%$ of calcium oxide and with no treatment and a same concentrate fixed at $1 \%$ of body weight. All roughage was corrected to contain $10 \%$ of crude protein. It was used five rumen-fistulated bovine with average weight of $240 \pm 15 \mathrm{~kg}$, distributed in a $5 \times 5$ Latin square. Abomasum and total fecal collection and two rumen evacuations were carried out in the morning. Animals fed corn silage based diet presented greater rumen digestibility of the protein and intestinal digestibility of the ether extract, greater intake and passage of dry matter, justifying greater intakes of dry matter and neutral detergent fiber corrected for protein and ash (NDFap). The greatest passage rates in animals fed fresh sugar cane based diet justify greater intakes of dry matter and NDFap in relation to the one observed with sugar cane silage supply. Animal consuming corn silage diets present greater dry matter passage rate and NDFap digestion. Diets with fresh sugar cane, stored or not, favor dry matter passage rate and intake, in relation to ensiled sugar cane. The use of calcium oxide in the ensilage does not improve nutrient digestibility neither passage rate of the diet. Sugar cane stored for 72 hours has digestible traits similar to the ones of fresh sugar cane.

Key Words: digestion, dry matter, intake, NDF, passage rate, ruminants

\section{Digestibilidade total e parcial, taxas de digestão obtidas com o esvaziamento ruminal e síntese de proteína microbiana em bovinos alimentados com cana-de-açúcar fresca ou ensilada e silagem de milho}

RESUMO - Avaliaram-se os consumos, as digestibilidades ruminal e intestinal e as taxas de passagem e de digestão de nutrientes em bovinos alimentados com dietas constituídas de silagem de milho, cana-de-açúcar triturada e fornecida in natura, cana triturada e ofertada após 72 horas de armazenamento, cana-de-açúcar ensilada com $1 \%$ de cal e sem tratamento e um mesmo concentrado fixado em $1 \%$ do peso corporal. Todos os volumosos foram corrigidos com ureia/sulfato de amônio para conterem $10 \%$ de proteína bruta. Utilizaram-se cinco bovinos fistulados no rúmen, com peso médio de $240 \mathrm{~kg} \pm 15 \mathrm{~kg}$, distribuídos em um quadrado latino $5 \times 5$. Foram realizadas coletas totais de fezes, abomasal e dois esvaziamentos pela manhã. Os animais alimentados com dietas à base de silagem de milho apresentaram maiores digestibilidades ruminal da proteína e intestinal do extrato etéreo, taxas de ingestão, passagem e de digestão da matéria seca, justificando os maiores consumos de matéria seca e fibra em detergente neutro corrigida para cinzas e proteína (FDNcp). As maiores taxas de passagem nos animais alimentados com dietas à base de cana-de-açúcar in natura justificam os maiores consumos de matéria seca e FDNcp em relação ao observado com o fornecimento de silagens de cana-de-açúcar. Animais consumindo dietas contendo silagem de milho apresentam maiores taxas de passagem da matéria seca e digestão da FDNcp. Dietas contendo cana-de-açúcar in natura, armazenada ou não, favorecem o consumo e a taxa de passagem da matéria seca, em relação a dietas com cana ensilada. O uso de cal na ensilagem não melhora a digestibilidade dos nutrientes nem a taxa de passagem da dieta. A cana-de-açúcar armazenada por 72 horas possui características digestíveis semelhantes às da cana-de-açúcar in natura.

Palavras-chave: consumo, digestão, FDN, matéria seca, ruminantes, taxa de passagem 


\section{Introduction}

Sugar cane is characterized by being a roughage widely known by the producers and considered to be of low cost because of its high production and facility of cultivation. The use of sugar cane, fresh or ensiled, involves logistic problems or material losses during a long period ensilage. Many works have been carried out to improve quality or to suggest alternatives which increase use efficiency of this roughage. Among the alternatives to improve fermentative profile and dry matter, there is an interest in using calcium oxide (Baleiro Neto et al., 2009; Oliveira et al., 2007; Cavali et al., 2010), recommended at levels up to $1.5 \%$ of fresh matter. However, little is known on the effects of this additive on physiological parameters of the animal. Chizzotti et al. (2009), in a study with crossbred steers fed diets with untreated sugar cane silage (control) and sugar cane treated with $0.5,1.0$ and $1.5 \%$ of calcium oxide, verified that addition of $0.5 \%$ of calcium oxide in sugar cane silage improved animal performance.

An option to soften problems caused by cut and transportation of sugar cane was proposed by Pina et al. (2011), who, by storing crushed sugar cane for three days, observed animal performance similar to the one obtained with supply of sugar cane crushed and immediately given to the animals.

To explain results of performance, there is a need to evaluate rumen digestion, production of microbial protein and passage rates and digestion of the diet constituents. To obtain those results, it is necessary in vivo measures, that is, animals fistulated at different segments of the gastrointestinal tract and using rumen pool (obtained by rumen evacuation) and the nutrient flow for obtaining rates of passage and digestion of the nutrients (Allen \& Linton, 2007).

This study was carried out to estimate total and partial digestibility, rates of rumen passage and digestion as well as $\mathrm{pH}$ and concentration of rumen ammonium, and to evaluate microbial protein synthesis in animals fed diets based on fresh or ensilaged sugar cane and corn silage.

\section{Material and Methods}

It was used five animals fistulated in the rumen and abomasum, with initial average body weight (BW) of $240 \pm 15 \mathrm{~kg}$, distributed in a $5 \times 5$ Latin square. Diets were formulated with one of the following roughages and given ad libitum: corn silage, crushed sugar cane and fresh supplied; crushed sugar cane and stored for 72 hours before supply, silage of sugar cane with no treatment; and silage of sugar cane added with 1.0 of calcium oxide (Table 1 ). All roughage were corrected with urea and ammonium sulfate to contain approximately $10 \%$ of crude protein (CP) on the basis of dry matter (DM), administrated immediately before supply. The same concentrate, at the basis of $1 \%$ of the body weight was given for all the animals, and it contained $23 \%$ of CP. Proportion of the ingredients in the concentrate total mixture were: corn meal - $87.60 \%$; soybean meal - $11 \%$; limestone - $0-80 \%$; salt $-0.65 \%$ and mineral mixture - 0-65\%, which contained (per kg of the product):

Table 1 - Composition of the roughage corrected with urea and concentrate used in the experimental diets

\begin{tabular}{|c|c|c|c|c|c|c|}
\hline \multirow[b]{2}{*}{ Evaluated parameter } & \multicolumn{5}{|c|}{ Roughage } & \multirow[t]{2}{*}{ Concentrate } \\
\hline & $\begin{array}{l}\text { Corn } \\
\text { silage }\end{array}$ & $\begin{array}{c}\text { Fresh } \\
\text { sugar cane }\end{array}$ & $\begin{array}{l}\text { Sugar cane stored } \\
\text { for } 72 \text { hours }\end{array}$ & $\begin{array}{l}\text { Silage of sugar cane } \\
\text { without treatment }\end{array}$ & $\begin{array}{l}\text { Silage of sugar cane } \\
\text { with calcium oxide (1\%) }\end{array}$ & \\
\hline Dry matter & 26.31 & 27.21 & 28.21 & 21.90 & 23.14 & 89.76 \\
\hline Organic matter & 95.40 & 94.57 & 95.04 & 95.40 & 94.00 & 94.50 \\
\hline Crude protein & 12.20 & 10.80 & 10.40 & 11.70 & 11.40 & 23.14 \\
\hline Non-protein nitrogen & 6.08 & 7.73 & 7.52 & 6.65 & 6.77 & - \\
\hline Urea & 1.15 & 2.30 & 2.28 & 1.92 & 2.02 & - \\
\hline Ether extract & 3.60 & 2.28 & 2.60 & 2.68 & 2.80 & 3.24 \\
\hline $\begin{array}{l}\text { Neutral detergent fiber corrected for } \\
\text { ash and protein }\end{array}$ & 51.42 & 46.92 & 53.04 & 62.00 & 54.50 & 17.89 \\
\hline Non-fibrous carbohydrates & 38.66 & 43.33 & 39.68 & 38.69 & 39.70 & 50.23 \\
\hline Acid detergent fiber (sequential) & 33.45 & 33.29 & 35.52 & 43.82 & 42.76 & 7.02 \\
\hline Indigestible neutral detergent fiber & 15.00 & 22.88 & 22.31 & 25.29 & 22.85 & 1.60 \\
\hline Indigestible acid detergent fiber & 9.08 & 13.07 & 14.13 & 14.16 & 11.01 & 0.90 \\
\hline Lignin & 5.21 & 6.51 & 6.13 & 8.41 & 7.28 & 1.20 \\
\hline Ethanol & - & - & - & 3.57 & 0.56 & - \\
\hline Acetic acid & - & - & - & 2.59 & 2.35 & - \\
\hline Butyric acid & - & - & - & 0.04 & 0.07 & - \\
\hline Lactic acid & - & - & - & 4.33 & 4.83 & - \\
\hline Propionic acid & - & - & - & 0.79 & 0.97 & - \\
\hline $\mathrm{pH}$ & - & - & - & 3.53 & 4.20 & - \\
\hline
\end{tabular}


calcium - 240 g; iodine - 90 mg; phosphorus - 174 g; magnesium - 2,000 mg; zinc - 5,270 mg; selenium - 15 mg; cobalt - $100 \mathrm{mg}$; fluorine - 1,740 mg, copper - 1,250 mg; iron $1,795 \mathrm{mg}$; vehicle q.s.p. $-1,000 \mathrm{~g}$.

At the beginning of the treatment, the animals were weighed, identified, vermifuged and kept for 14 days for adaptation to the experimental diets and facilities which were composed of covered roof, concrete floor and individual drinkers and troughs. During this adaptation phase, experimental diets were given ad libitum, twice daily, in the morning and in the afternoon. Each experimental period was consisted of 14 days: seven days for adaptation to the diet and seven days for sample collection.

For determination of the flow of abomasum dry matter, titanium dioxide was given to the animals from the $2^{\text {nd }}$ to the $10^{\text {th }}$ day of each experimental period, at the amount of $15.0 \mathrm{~g}$ per animal. The marker was put in paper cartridge and directly placed in the rumen at a single dose daily at 10 a.m.

Fecal total collections were performed from the $8^{\text {th }}$ to the $10^{\text {th }}$ day of each experimental period. It was collected approximately $200 \mathrm{~mL}$ of abomasal digesta in 15-hour intervals, totaling six samples per animal (Allen \& Linton, 2007). On the $11^{\text {th }}$ day, rumen fluid collection was performed before feeding in the morning, 2, 4 and 6 hours after diet supply, for determination of $\mathrm{pH}$ and concentration of rumen ammoniacal nitrogen. Evaluations of $\mathrm{pH}$ were carried out immediately after collection by using digital potentiometer. For quantification of rumen ammoniacal nitrogen, a $50-\mathrm{mL}$ aliquot was separated, fixed with $1.0 \mathrm{~mL}$ of $\mathrm{H}_{2} \mathrm{SO}_{4}(1: 1)$, put in a plastic container, identified and frozen at $-15^{\circ} \mathrm{C}$ for further laboratory analyses. Also, 4 hours after feeding, blood collection was done by punction of the jugular vein by using tubes with coagulation accelerator gel for determination of urea concentration in the serum. Blood samples were centrifuged at $10000 \mathrm{~g}$ for 15 minutes, and the resulting serum stored at $-15^{\circ} \mathrm{C}$ for determination of urea content. On the same $11^{\text {th }}$ day, six hours after feeding, collections for bacteria isolation were done. Bacteria isolation was done according to the technique described by Cecava et al. (1990). On the $12^{\text {th }}$ day of each collection period, a total evacuation of the rumen was done 4 hours after diet supply in the morning, to determine passage rate and digestion of the nutrients, of each diet according to the technique described by Allen \& Linton (2007). On the $14^{\text {th }}$ day, rumen evacuation was repeated immediately after the diet was given. After rumen evacuation, total digesta weight was evaluated, which was after filtrated through four layers of gaze for obtaining weights of the solid and liquid phases, which were sampled for determination of the contents of dry matter and NDF. After sampling, the phases were mixed again and digesta was returned to the rumen. Ingestion rate was calculated by dividing daily intake of dry matter of NDF by the respective rumen pool, and the passage rate was obtained by dividing flow of dry matter or the nutrients in the abomasum by rumen pool. Digestion rates were obtained by subtracting ingestion rate by passage rate (Allen \& Linton, 2007).

At the end of each experimental period, samples of food, feces, digesta of abomasum and of food scraps were submitted to drying at $60^{\circ} \mathrm{C}$ for 72 hours, then they were ground in a knife mill with a 1-mm sieve and stored in plastic containers for laboratorial analyses. Samples of feces, food scraps and abomasal digesta were composed of animal in each period, based on the pre-dry weight. Analyses of dry matter (DM), total nitrogen (TN), ether extract (EE), organic matter (OM), non-protein nitrogen (NPN) and lignin (H2SO4 72\% p/p) were done by following procedures described by Silva \& Queiroz (2002), whereas evaluations of NDF and ADF followed methods described by Mertens (2002) and Van Soest \& Robertson (1985), respectively. For determination of indigestible neutral detergent fiber (NDFi), samples of all roughages, of the concentrate and of the food scraps were incubated in the rumen of an animal for 264 hours as suggested by Casali et al. (2008), by using F57 bags (Ankom). Non fibrous carbohydrates (NFC) were calculated as proposed by Hall (2000): NFC $=100-[(\% C P-\% C P$ derived as urea + $\%$ de urea) + \% NDFap + \% EE + \%ash].

Contents of ethanol, volatile fatty acids (VFA) and lactic acid were determined in aqueous extracts of the silage samples, obtained by following the method described by Kung Júnior (1996). To do so, $25 \mathrm{~g}$ of the wet sample were processed with $225 \mathrm{~mL}$ of Ringer solution in a blender for 1 minute. After that, the material was filtrated in Whatman ${ }^{\circledR}$ 54 filter-paper, acidified with sulfuric acid at $50 \%$ and centrifuged (5,000 g) for 15 minutes. Afterwards, the liquid extract was stored in a freezer $\left(-50^{\circ} \mathrm{C}\right)$ until performance of analyses. Before filtering, $\mathrm{pH}$ was determined by using digital $\mathrm{pH}$ meter. Content of ethanol was determined in a gas chromatographer model CG-17A, Shimadzu, equipped with FID. For registration and analyses of chromatograms, the gadget was coupled to a microcomputer by using GC Solution program. The compounds were separated and identified in a capillary column PAG $(30 \mathrm{~m} \times 0.25 \mathrm{~mm})$. For chromatographic separation, $1 \mu \mathrm{L}$ of the sample was injected by using a $10 \mu \mathrm{L}$ $\left(\right.$ Hamilton ${ }^{\circledR}$ ) syringe in a Split $=30$ system. Nitrogen gas was used as a carrier with a linear velocity programmed for $24.64 \mathrm{~cm} / \mathrm{s}$ and the synthetic air and hydrogen gas formed a flame in the detector. Temperatures in the injector and detector were isothermally controlled between $200^{\circ} \mathrm{C}$ and 
$220^{\circ} \mathrm{C}$. The initial temperature in the column was $100^{\circ} \mathrm{C}$ (kept for 6 minutes), increasing at $30^{\circ} \mathrm{C}$ per minute up to $180^{\circ} \mathrm{C}$ (kept for 24 minutes) totaling 11.06 minutes of analyses. Flow drag gas in the column was $0.8 \mathrm{~mL} /$ minute. Contents of lactic acid were determined by high performance liquid chromatography (HPLC) in a Shimadzu gadget, SPD-10A VP model, coupled to an ultra-violet detector by using wave length of $210 \mathrm{~nm}$. It was used a SCR-101 H column, with $30 \mathrm{~cm} \times 7.9 \mathrm{~mm}$ of diameter with a flow in the column of $0.8 \mathrm{~mL} / \mathrm{minute}$ at $24 \mathrm{kgf}$. The mobile phase was constituted of water in $1 \%$ of ortophosphoric acid, at a rate of $20 \mu \mathrm{L}$. Acetic acid, propionic acid and butyric acid were determined in a gas chromatographer, CG-17 A model, Shimadzu, equipped with FID detector. For record and analyses of the chromatograms, the gadget was coupled to a microcomputer, by using the program GC Solution. Compounds were separated and identified in a Nukol capillary column (30 $\mathrm{m} \times 0.25 \mathrm{~mm}$ ). For chromatographic separation, $1 \mu \mathrm{L}$ of the sample was injected by using a $10 \mu \mathrm{L}$ (Hamilton ${ }^{\circledR}$ ) syringe in a Split $=5$ system. Nitrogen gas was used as a carrier with a linear velocity programmed for $43.2 \mathrm{~cm} / \mathrm{s}$ and hydrogen gas and synthetic air formed the flame in the detector. Temperatures in the injector and detector were isothermally controlled between $220^{\circ} \mathrm{C}$ and $250^{\circ} \mathrm{C}$. The initial temperature in the column was $100^{\circ} \mathrm{C}$ (kept for 5 minutes), increasing at $10^{\circ} \mathrm{C}$ per minute until reaching $185^{\circ} \mathrm{C}$ (kept for 20 minutes) totaling 33.5 minutes of analysis. Flow drag gas in the column was $1.0 \mathrm{~mL} /$ minute.

Urea concentration was determined in the serum, following diacetyl modified method (commercial kits). Nitrogen urea concentration in the serum (NUS) was obtained by a product from urea concentration multiplied by 0.466 corresponding to the content of $\mathrm{N}$ in the urea.

For quantifying rumen digesta microorganisms, it was used purine base, whose determination followed technique described by Ushida et al. (1985). Microbial N flow in abomasal digesta was calculated by using $\mathrm{N}$ purine: $\mathrm{N}$ total relationship, obtained in the experiment. Concentrations of $\mathrm{N}-\mathrm{NH}_{3}$ filtrated rumen liquid were determined by destillation with $2 \mathrm{~N}$ potassium hydroxide, according to technique by Fenner (1965). Evaluations of $\mathrm{pH}$ variables and ammonium rumen concentration were carried out by time repeated measures (Kaps \& Lamberson, 2004). The results were evaluated by PROC MIXED SAS (SAS, 2000), by using 0.05 as probability critical level for Type I error.

Comparisons among means were done by orthogonal contrasts by using for all procedures $5 \%$ level of significance and statistical analyses were done by using SAS program. The following contrasts were used: $1=$ diets with corn silage versus other diets; 2 = diets with fresh sugar cane (fresh sugar cane and sugar cane stored for 72 hours) versus diets with sugar cane silage (silage of sugar cane without treatment with calcium oxide 1\%); 3 = sugar cane silage without treatment versus silage of sugar cane treated with $1 \%$ of calcium oxide $1 \%$; and 4 = sugar cane stored for 72 hours versus fresh sugar cane.

\section{Results and Discussion}

When intakes of dry matter and NDFap were expressed in relation to body weight $(\mathrm{BW})$, they were greater $(\mathrm{P}<0.05)$ when animals were fed corn silage diets, a characteristic which was repeated when fresh sugar cane and sugar cane stored for 72 hours diets were supplied (Table 2). When they were expressed in kg/day, intakes of dry matter, organic matter, non-fibrous carbohydrates (NFC) and total digestible nutrients (TDN) were greater $(\mathrm{P}<0.05)$ when animals were fed diets with fresh sugar cane than those fed diets with sugar cane silage.

Intake of NDFap in percentage of body weight (\%BW) were greater $(\mathrm{P}<0.05)$ when diet with sugar cane stored for 72 hours was given in relation to diets with fresh sugar cane. Animals fed diets with ensilaged sugar cane presented greater $(\mathrm{P}<0.05)$ intakes of NDFi $(\% \mathrm{BW})$. Regardless to the manner in which they were expressed, there were no effects of calcium oxide addition in sugar cane silage $(\mathrm{P}>0.05)$ on intakes of any of the dietary components.

The greatest intakes of dry matter and neutral detergent fiber corrected for ash and protein (NDFap), expressed in \% of body weight, obtained with corn silage diets can be explained by the lower intakes of indigestible fiber (NDFi) of these diets inasmuch as lower contents of NDFi result in greater passage rates (Table 4) and greater intakes. The same explanation can be given for greater intakes of dry matter and NDFap calculated on the basis of body weight of diets with fresh sugar cane in relation to those with sugar cane silage.

By evaluating total apparent digestibility, it is noted that corn silage diet led animals to greater digestibility $(\mathrm{P}<0.05)$ of organic matter, NDFap and ether extract than the other diets (Table 2). It was noted greater total apparent digestibility $(\mathrm{P}<0.05)$ of dry matter and organic matter, NFC and TDN when fresh sugar cane diets (sugar cane and 72-hour sugar cane) were given in relation to diets with sugar cane silage. Storage of sugar cane for 72 hours before being given to the animals does not harm $(\mathrm{P}>0.05)$ total digestibility of the dietary components. Treatment of sugar cane silage with $1 \%$ of calcium oxide did not change total apparent digestibility of the dietary components, except for crude protein digestibility, which increased $(\mathrm{P}<0.05)$. 
Table 2 - Intake and total apparent digestibility of diets with fresh or ensilage sugar cane and corn silage for confined beef cattle

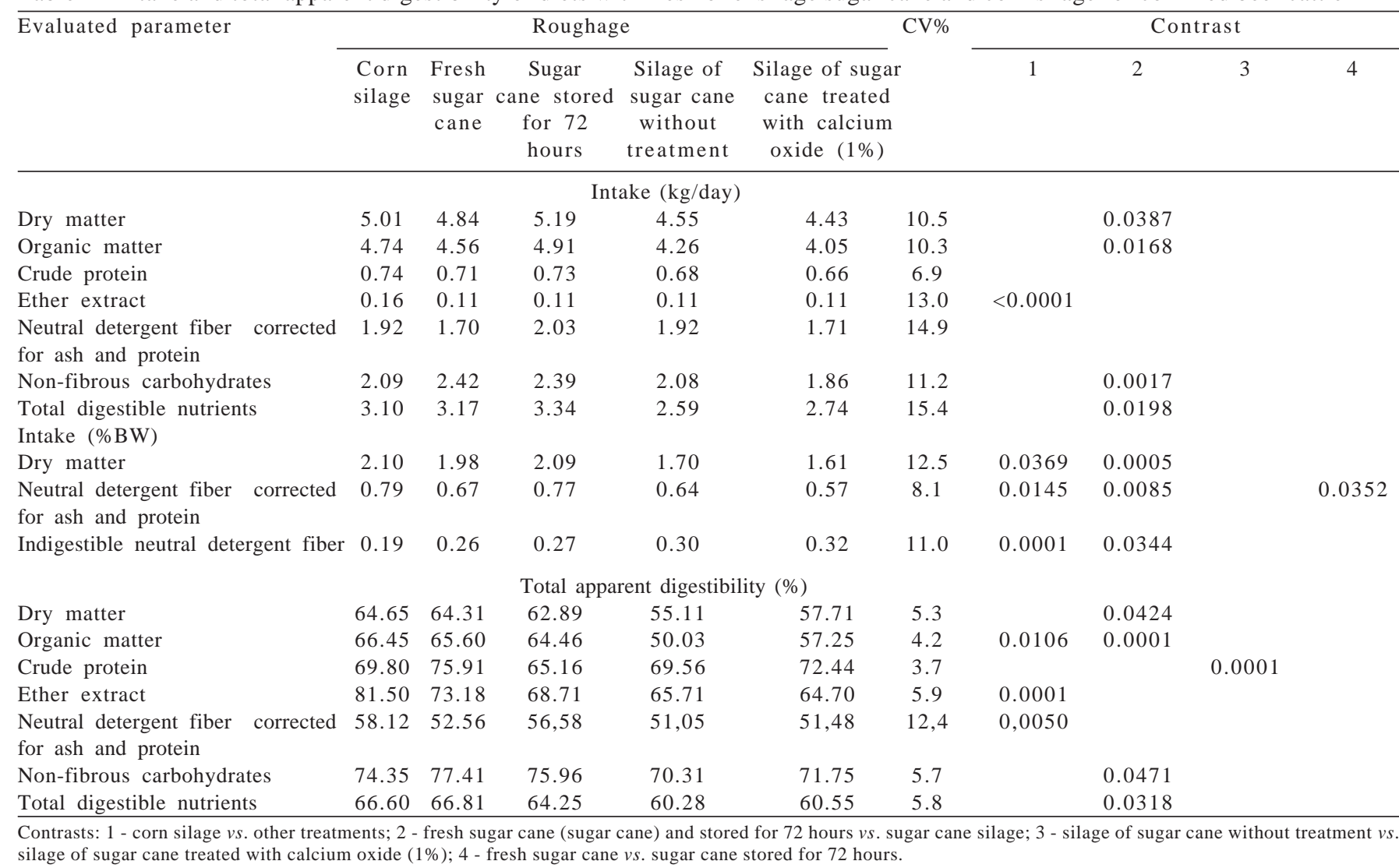

The greater content of TDN in fresh sugar cane diets can be partially explained by their lower content of lignin (6.51 in the fresh sugar cane diet and 6.3 in the sugar cane stored for 72 hours diet) in relation to those with sugar cane silage (8.4 in the diet with silage of sugar cane without treatment and 7.3 in the diet with silage of sugar cane treated with calcium oxide), but, the intake and digestibility of nonfibrous carbohydrates were greater $(\mathrm{P}<0.05)$ when diets with fresh sugar cane were given, leading to greater values of TDN. Sugar cane silage causes losses during fermentation, which in turn promote greater intakes of NDFi and higher concentrations of lignin, with lower contents of NFC which probably reduced content of TDN in ensilaged sugar cane diets. The greater digestibility of organic matter obtained in cattle fed corn silage diets can be explained by greater rates of digestion of NDFap of those diets in relation to those with sugar cane.

When sugar cane silage is compared, it is noted inefficiency of the additive in improving nutritional values of the ensilaged material, promoting only improvement in total apparent digestibility of crude protein. These results are similar to the ones reported by Pontes (2007), who concluded on the little action of calcium oxide, which did not promote any increase on the digestibility of the dietary components. These results are against the principle of hydrolysis, which is based on the phenomenon known as "cellulose alkaline swelling", which is consisted in the expansion and rupture of cellulose molecules (Jackson, 1977), which in turn would improve the use of fiber by rumen microorganisms.

The results obtained with the use of calcium oxide are in disagreement with the ones in the literature: Amaral et al. (2009) noted an improvement on fermentation pattern and on the quality of silage of sugar cane with $1 \%$ of calcium oxide. Baleiro Neto et al. (2009) found greater losses of dry matter with doses smaller than $1 \%$ whereas the value of $2 \%$ led to the lowest losses of dry matter when $0 ; 0.5 ; 1$ and $2 \%$ of calcium oxide were used.

Diets with sugar cane stored for 72 hours caused results of intake and digestibility of nutrients similar $(\mathrm{P}>0.05)$ to the ones obtained with sugar cane crushed and immediately given to the animals. Storage of sugar cane did not change NDFap digestibility in the animals, evidencing that although there was fermentation during storage, this fermentation did not influence NDFap digestibility. Pina et al. (2011) noted that storage of sugar cane for three days caused an increase on NDFap intakes and a decrease on their digestibility. This author also reported that dietary 
content of non-fibrous carbohydrates was reduced, possibly because of the fermentation during storage, influencing negatively content of TDN with the increase of storage time of sugar cane.

In this study, when corn silage diets were given, animals presented greater $(\mathrm{P}<0.05)$ rumen digestibility of crude protein and intestinal digestibility of ether extract and lower $(\mathrm{P}<0.05)$ intestinal digestibility of crude protein and ether extract (Table 3). When fed fresh sugar cane diets, animals presented lower $(\mathrm{P}<0.05)$ rumen digestibility of $\mathrm{OM}, \mathrm{CP}$, and NFC and greater digestibility $(\mathrm{P}<0.05)$ of EE. The animals also presented greater $(\mathrm{P}<0.05)$ intestinal digestibility of $\mathrm{DM}, \mathrm{OM}$ and NFC in relation to those fed ensilaged sugar cane based diet.

When sugar cane silage supplies were compared, there was a similarity $(\mathrm{P}>0.05)$ among rumen digestibility of all nutrients. However, diets with silage of sugar cane treated with calcium oxide led animals to greater $(\mathrm{P}<0.05)$ intestinal digestibility of crude protein.

Rumen and intestinal digestibility, of all nutrients, did not differ $(\mathrm{P}>0.05)$ among diets with sugar cane stored for 72 hours and those with fresh sugar cane. Nitrogen source can influence intake and digestibility of the diet, but Silveira et al. (2009) did not note any differences on dry matter intake when urea, corn gluten and soybean meal and sugar cane as roughage were used, and they found total rumen, intestinal and apparent digestibility similar among the diets.

The greatest values of ingestion rates of dry matter and NDFap $(\mathrm{P}<0.05)$ were obtained when corn silage diets were given (Table 4). Dry matter ingestion rate was greater $(\mathrm{P}<0.05)$ when fresh sugar cane diets were given in relation to those animals fed sugar cane silage diet. There were any differences $(\mathrm{P}>0.05)$ for any of the contrasts studied for NDFi ingestion rate. Passage rates of dry matter and NDFap were greater $(\mathrm{P}<0.05)$ when animals were fed corn silage diet in relation to those diets with sugar cane; fresh sugar cane diets were superior to those with sugar cane silage.

Rates of dry matter and NDFap digestion were greater $(\mathrm{P}>0.05)$ when animals were fed corn silage diets. There were no differences $(\mathrm{P}>0.05)$ on rates of dry matter and NDFap digestion among sugar cane diets. When rumen pool size of dry matter and NDFap were evaluated, it was noted that sugar canes diets led animals to greater pool $(\mathrm{P}<0.05)$ in relation to corn silage diets; pool of animals fed ensilaged sugar cane diet was superior to the one noted with the supply of fresh sugar cane diets. In a certain way, corn silage diets promoted greater dry matter ingestion, which caused an increase of digestibility of fibrous compounds with high power of rumen repletion (Sampaio et al., 2009). According to Allen (1996), processes of degradation and passage should be evaluated in an integrated manner inasmuch as the velocity of use of potentially degradable compound by microorganisms is enlarged, the time needed by the particle to reach the specific density band which is able to be occupied for removal of posterior tract is reduced. Therefore, it can be realized that by associating NDF traits, the pool size and insoluble fiber of the sugar cane based diets, there is an outstanding knowledge on the concept of

Table 3 - Rumen and intestinal digestibility of diets with fresh or ensilaged sugar cane and corn silage obtained from beef cattle

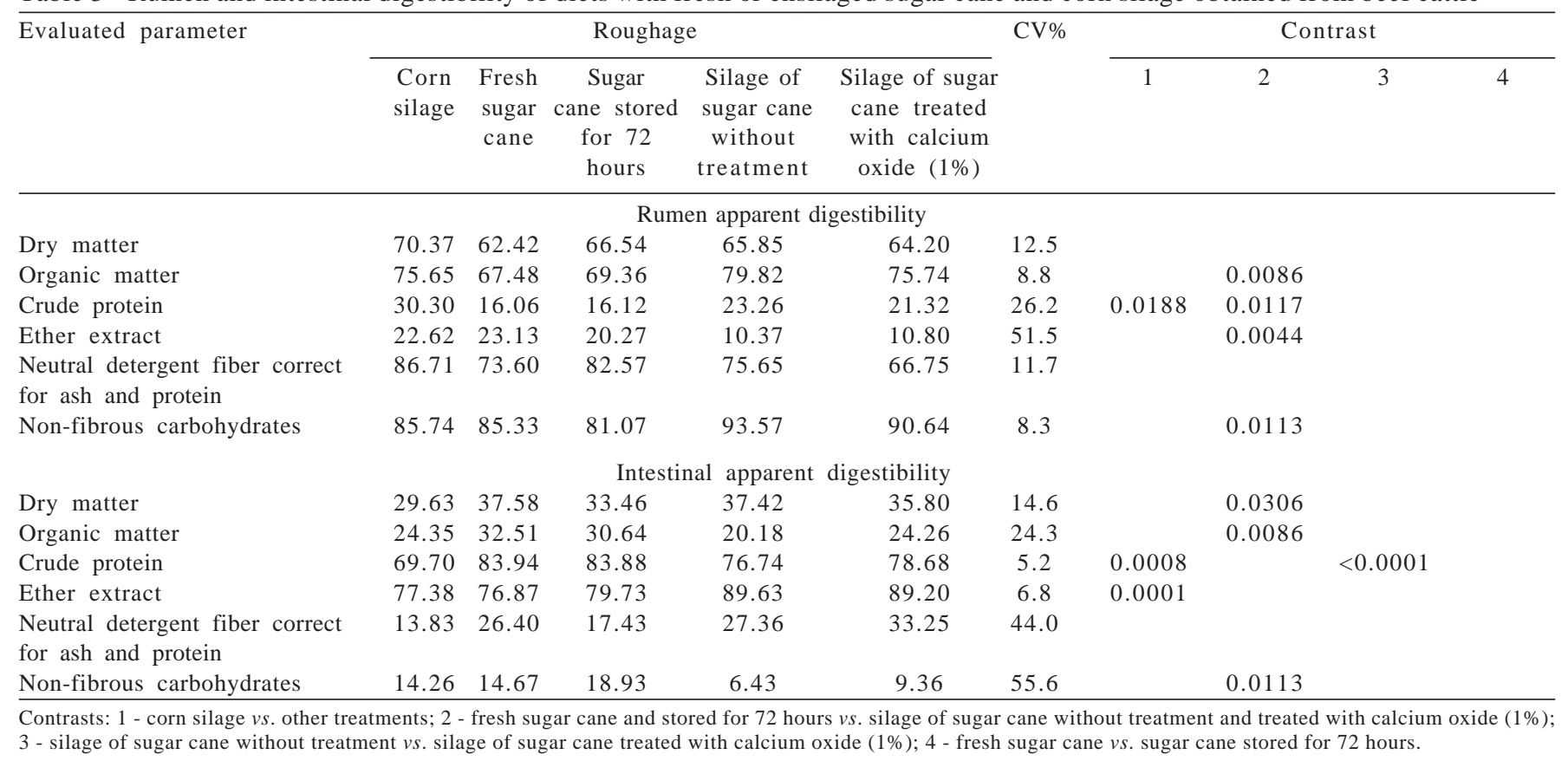


Table 4 - Ingestion, passage and digestion rates and pool size obtained from bovine fed fresh or ensiled sugar cane and corn silage

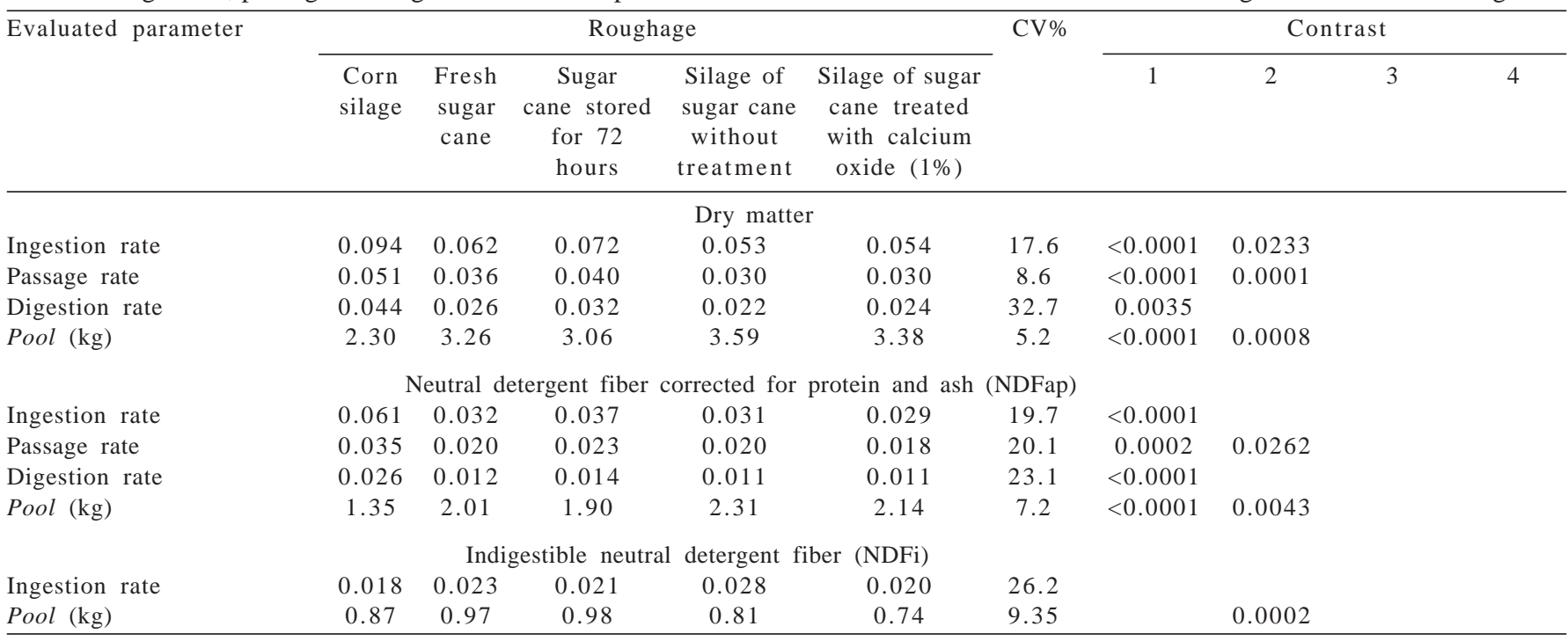

Contrasts: 1 - corn silage vs. other treatments; 2 - fresh sugar cane vs. sugar cane silage (treated or not treated with $1 \%$ of calcium oxide; 3 - silage of sugar cane without treatment vs. silage of sugar cane with calcium oxide (1\%); 4 - fresh sugar cane vs. sugarccane stored for 72 hours.

rumen repletion by the capacity of occupying space and consequently to physically influence the intake.

By taking into account the ingestion rates of NDFi of the experimental diets, it can be inferred that NDFi is another variable with a fundamental role on the control of dry matter intake because the dry matter intakes were numerically different, but ingestion rates of NDFi were constant.

Ingestion and passage rates of dry matter were greater $(\mathrm{P}<0.05)$ when corn silage diets were given, and those rates were also greater $(\mathrm{P}<0.05)$ when it was given fresh sugar cane diets, compared to those sugar cane silage diets. The greatest passage rate explains the greatest intake and it results in a better animal performance, as it was noted by Menezes (2010), who reported that animals fed corn silage present better daily weight gain $(1.5 \mathrm{~kg})$ and that animals fed fresh sugar cane based diets presented better performance in relation to those fed ensilaged sugar cane based diet, whose daily average gains were $1.09 \mathrm{~kg} \times 0.93 \mathrm{~kg}$, respectively.

The use of calcium oxide in the ensilage of sugar cane was not able to modify rates of ingestion, passage and digestion of dry matter and NDFi in relation to ensilage of sugar cane without additive, a fact that possibly justify the similarity on performance of bovine found by Menezes (2010), with daily weight gains of $0.94 \mathrm{~kg}$ and $0.92 \mathrm{~kg}$ for silage of sugar cane with or without calcium oxide, respectively.

Passage rate in the rumen determines digesta flow through gastrointestinal tract, which, for tropical forage, show low values especially because of the high content of low degradability fiber which has an effect of rumen repletion (Fernandes et al., 2003). The greatest digestion rates of dry matter and NDFap observed in animals fed corn silage diets also justify the greatest intake of nutrients obtained with this diets in relation to those animals fed sugar cane diets.

It was not noted any effect $(\mathrm{P}>0.05)$ of diets on composition of rumen microorganism or on microbial efficiency (Table 5). However, fresh sugar cane diets caused greater $(\mathrm{P}<0.05)$ concentration of microbial nitrogen in animals in relation to ensilaged sugar cane diets, but concentration of SUN did not differ $(\mathrm{P}>0.05)$ among diets.

The greatest concentration of serum urea nitrogen in animals fed sugar cane based diet is probably related to a greater participation of urea in these diets in relation to those diets with corn silage. The values obtained for serum urea nitrogen indicate high production of ammonium in the rumen, which causes losses of dietary protein. According to Preston et al. (1965), there is a positive correlation among nitrogen ingestion in the diet and concentration of serum urea nitrogen.

According to Valadares et al. (1997), concentrations of nitrogen compound in the plasma and urea nitrogen are related, and values from 13.0 to $15.0 \mathrm{mg} / \mathrm{dL}$ of nitrogen in the plasma would represent limits from which losses of dietary protein would be occurring. However, it has not been reported yet the urea plasma concentration from which it could be stated that it would be occurring loss of protein, inefficient use of nutrient or inadequate nutrititional condition (Valadares et al., 1997).

To estimate rumen microbial composition in different food experimental conditions is important because it allows 
Table 5 - Rumen microorganism composition in bovine fed diets with fresh or ensiled sugar cane and corn silage

\begin{tabular}{|c|c|c|c|c|c|c|c|c|c|c|}
\hline Evaluated parameter & \multicolumn{5}{|c|}{ Roughage } & $\mathrm{CV} \%$ & \multicolumn{4}{|c|}{ Contrast } \\
\hline \multicolumn{11}{|c|}{ Microorganism composition (\%) } \\
\hline Dry matter & 92.45 & 92.45 & 92.78 & 93.09 & 93.00 & 0.96 & & & & \\
\hline N-RNA/TN ${ }^{1}$ & 15.59 & 15.49 & 14.74 & 16.77 & 15.70 & 10.03 & & & & \\
\hline Microbial nitrogen g/day & 74.65 & 70.93 & 70.89 & 50.13 & 50.79 & 8.34 & & $<0.0001$ & & \\
\hline Efficiencykg/TDNNDT & 125.2 & 129.7 & 129.1 & 124.1 & 124.9 & 6.78 & & & & \\
\hline Serum urea nitrogen $(\mathrm{mg} / \mathrm{dL})$ & 17.68 & 19.88 & 18.63 & 19.28 & 19.09 & 15.81 & & & & \\
\hline
\end{tabular}
sugar cane vs. sugar cane stored for 72 hours.

knowing the effects of the source and quantity of dietary protein on composition of rumen microorganisms (Pina et al., 2011). There is a great variation on chemical composition of rumen microorganisms described in literature and this variation is probably due to differences among techniques used to isolate them and, or, to measure their composition in addition to other differences related to the diet profile (Oliveira et al., 1999). Clark et al. (1992) reviewed works and described variations on microbial composition for organic matter, total nitrogen and N-RNA/TN at the order from 60.8 to $92.2 \%$; from 4.82 to $10.58 \%$; and from 7.25 to $17.86 \%$, respectively. Values related to composition of rumen microorganisms of this experiment are found within the range described by these authors.

Microbial efficiency was not influenced $(\mathrm{P}>0.05)$ by experimental diets, and the values found were close to the ones cited by NRC (2001), which considers $13.0 \mathrm{~g} \mathrm{CP} / 100 \mathrm{~g}$ of TDN, and Valadares Filho et al. (2006), values of $12.0 \mathrm{~g}$ CPmic/100 g TDN, in tropical conditions. Concentration of $\mathrm{N}-\mathrm{NH}_{3}$ was influenced $(\mathrm{P}<0.05)$ by sample collection time, but it was not noted any effect $(\mathrm{P}>0.05)$ from the diets supplied (Figure 1).

Values found in this experiment are favorable for the adequate food fermentation occurrence in the rumen. Detmann et al. (2009), based on tropical conditions, verified that the concentration from 8 to $15 \mathrm{mg} / 100 \mathrm{~mL}$ of ammoniacal nitrogen in the rumen is sufficient for improvement of intake and degradation of NDF. Also considering climate conditions and the type of forage used in the tropics, Sampaio (2007) noted an increase of dry matter voluntary intake with concentration of $9.64 \mathrm{mg} / \mathrm{dL}$ of rumen $\mathrm{N}-\mathrm{NH}_{3}$ and the level of $5.32 \mathrm{mg} / \mathrm{dL}$ of $\mathrm{N}-\mathrm{NH}_{3}$ was necessary for the occurrence of microbial growth at the minimal level for maintenance of microbial synthesis and rumen degradation processes.

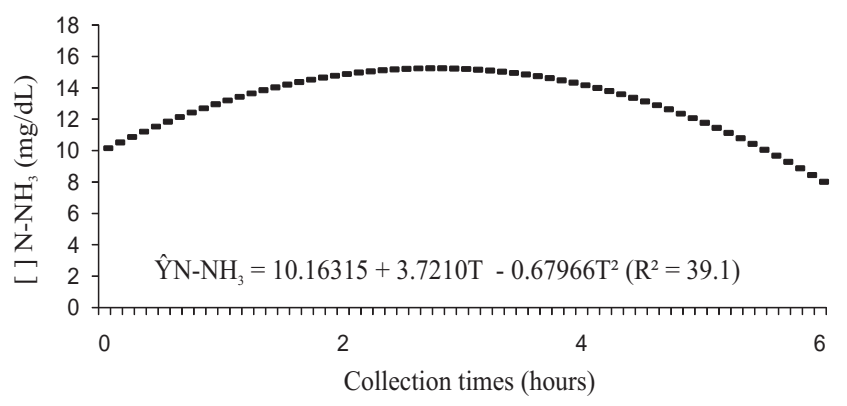

Figure 1 - Rumen $\mathrm{N}-\mathrm{NH}_{3}$ concentrations at various sample collection times.

Ammonium production peak was obtained 2.74 hours after giving the diet, when it was inferior to the one obtained at 3.8 hours as reported by Pina et al. (2011). Although some average values observed for ammonium production at 0 and 6 hours are low, they were superior to the ones proposed by Detmann et al. (2009), which $8 \mathrm{mg} / 100 \mathrm{~mL}$ of $\mathrm{N}-\mathrm{NH}_{3}$ would be sufficient for promoting maximal rates of microbial growth.

Rumen $\mathrm{pH}$ was not influenced $(\mathrm{P}>0.05$ ) by experimental diets and it presented quadratic behavior in function of collection time, with minimal value estimated at 5.99 hours after diet supply (Figure 2). The pH ranged from 6.47 to 7.00, evidencing that the inclusion of $1 \%$ of concentrate at the basis of body weight was not able to reach critical levels of $\mathrm{pH}$ to affect rumen fermentation. Considered as an important factor that affects rate and extension of digestion of fiber in the rumen, $\mathrm{pH}$ should be above 6.0 to enable greater use of forage by the ruminant (Hoover, 1986). These rumen $\mathrm{pH}$ values are within the ideal range for action of cellulosic bacteria in the rumen (Russel \& Wilson, 1996). The influence of urea on rumen $\mathrm{pH}$ was reported by Carmo et al. (2001), who, in a work with sugar cane containing soybean meal, corn gluten and associations with urea as nitrogen sources, noted that the presence of urea in the diets increased rumen 


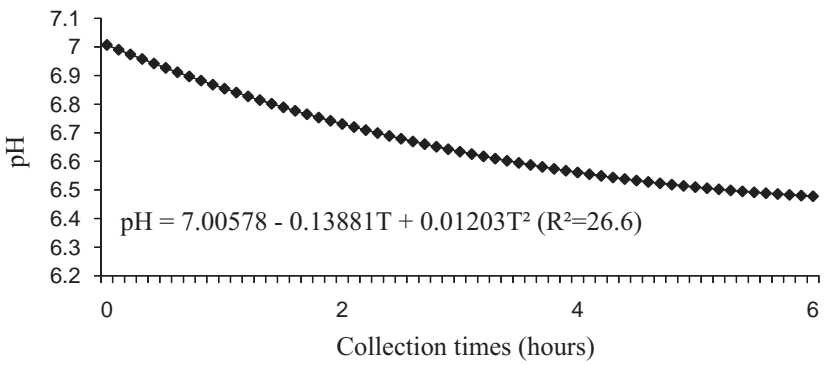

Figure 2 - Rumen pH at many sample collection times.

$\mathrm{pH}$ due to the release of ammonium, and that the $\mathrm{pH}$ was kept from 6.27 to 6.87 , values close to the ones obtained in this experiment.

\section{Conclusions}

Animals fed corn silage present greater dry matter passage rate and greater digestion rates of dry matter and neutral detergent fiber, which result in a greater intake of nutrients. The greater dry matter passage rate noted on animals fed fresh sugar cane diet justifies the greater intake in relation to ensilaged sugar cane diets. Sugar cane silage diets have similar effects on all digestive parameters, and the use of calcium oxide is unable to improve intake and digestibility in bovines. Sugar cane stored for 72 hours has digestible characteristics similar to the ones of fresh sugar cane given immediately after cut.

\section{References}

AMARAL, R.C.; PIRES, A.V.; SUSIN, I. et al. Cana-de-açúcar ensilada com ou sem aditivos químicos: fermentação e composição química. Revista Brasileira de Zootecnia, v.38, n.8, p.1413-1421, 2009.

ALLEN, M.S.; LINTON, J.A.V. In vivo methods to measure digestibility and digestion kinetics of feed fractions in the rumen. In. RENNÓ, F.P.; SILVA, L.F.P. (Eds.) SIMPÓSIO INTERNACIONAL AVANÇOS EM TÉCNICAS DE PESQUISA EM NUTRIÇÃO DE RUMINANTES, Pirassununga, 2007. Anais... Pirassununga 2007. p.72-89.

ALLEN, M.S. Physical constrainson voluntary intake of forages by ruminats. Journal of Animal Science, v.74, p.3063-3075, 1996.

BALIEIRO NETO, G.; FERRARI JUNIOR, E.; NOGUEIRA, J.R. et al. Perdas fermentativas, composição química, estabilidade aeróbia e digestibilidade aparente de silagem de cana-de-açúcar com aditivos químico e microbiano. Pesquisa Agropecuária Brasileira, v.44, n.6, p.621-630, 2009.

CARMO, C.A.; BERCHIELLI, T.T.; ANDRADE, P. et al. Degradabilidade da matéria seca e fibra em detergente neutro da cana-de-açúcar (Saccharum spp.) com diferentes fontes de proteína. Revista Brasileira de Zootecnia, v.30, n.6, p.2126-2133, 2001 (supl.).

CASALI, A.O.; DETMANN, E.; VALADARES FILHO, S.C. et al. Influência do tempo de incubação e do tamanho de partículas sobre os teores de compostos indigestíveis em limentos e fezes bovinas obtidos por procedimentos in situ. Revista Brasileira de Zootecnia, v.37, n.2, p.335-342, 2008.

CAVALI, J.; PEREIRA, O.G.; VALADARES FILHO, S.C. et al. Bromatological and microbiological characteristics of sugarcane silages treated with calcium oxide. Revista Brasileira de Zootecnia, v.39, n.7, p.1398-1408, 2010.

CECAVA, M.J.; MERCHEN, N.R.; GAY, L.C. et al. Composition of ruminal bacteria harvest from steers as influenced by dietary energy level, feeding frequency, and isolation techniques. Journal of Dairy Science, v.73, n.9, p.2480-2488, 1990.

CHIZZOTI, F.H.M.; PEREIRA, O.G.; VALADARES FILHO, S.C. et al. Dry matter intake and performance of steers fed sugar cane ensiled with different levels of calcium oxide. In: ADSACSAS-ASAS Joint Annual Meeting, 2009, Montreal. Journal of Animal Science, v.87, p.303-303, 2009.

CLARK, J.H.; KLUSMEYER, T.H.; CAMERON, M.R. Microbial protein synthesis and flows of nitrogen fractions to the duodenum of dairy cows. Journal of Dairy Science, v.75, p.2304-2323 1992.

DETMANN, E.; PAULINO, M.F.; MANTOVANI, H.C. et al. Parameterization of ruminal fibre degradation in low-quality tropical forage using Michaelis-Menten kinetics. Livestock Science, v.126, p.136-146, 2009.

FENNER, H. Method for determining total volatile bases in rumen fluid by steam distillation. Journal of Dairy Science, v.48, n.2, p.249-251, 1965.

FERNANDES, A.M.; QUEIROZ, A.C.; PEREIRA, J.C. et al. Fracionamento e cinética da degradação in vitro dos carboidratos constituintes da cana-de-açúcar com diferentes ciclos de produção em três idades de corte. Revista Brasileira de Zootecnia, v.32, n.6, p.1778-1785, 2003.

HALL, M.B. Neutral detergent-soluble carbohydrates, nutritional relevance and analysis. A laboratory manual. Florida: University of Florida, 2000. 42p. (Bulletin, 339).

HOOVER, W.H. Chemical factores involved in ruminal fiber digestion. Journal of Dairy Science, v.69, p.2755-2766, 1986.

JACKSON, M.G. The alkali treatments of straws. Animal Feed Science and Technology, v.2, n.2, p.105-130, 1977.

KAPS, A.M.; LAMBERSON, W.R. Biostatistics for animal science. London: CABI Publishing, 2004. 445p.

MENEZES, G.C.C. Cana-de-açúcar (Saccharum officinarum L.) in natura ou ensilada e silagem de milho em dietas para bovinos de corte confinados. 2010. 86f. Dissertação (Mestrado em Zootecnia) - Universidade Federal de Viçosa, Viçosa, MG.

MERTENS, D.R. Gravimetric determination of amylase treated neutral detergent fiber in feeds with refluxing in beakers or crucibles: collaborative study. Journal of AOAC International, v.85, n.6, p.1212-1240, 2002.

NATIONAL RESEARCH COUNCIL - NRC. Nutrient requirements of dairy cattle. 7.ed. Washington, D.C.: National Academic Press, 2001. 381p.

OLIVEIRA, M.D.S.; ANDRADE, A.T.; BARBOSA, J.C. et al. Digestibilidade da cana-de-acúcar hidrolisada, in natura e ensilada para bovinos. Ciência Animal Brasileira, v.8, n.1, p.41-50, 2007.

OLIVEIRA, R.L.; PEREIRA, J.C.; CARVALHO E SILVA, P.R. et al. Consumo, digestibilidade e balanço de nitrogênio em novilhos alimentados com cama de frango e suplemento à base de microbiota ruminal liofilizada. Revista Brasileira de Zootecnia, v.28, n.4, p.831-838, 1999.

PINA, D.S.; VALADARES FILHO, S.C.; TEDESCHI, L.O. et al. Níveis de inclusão e tempo de exposição da cana-de-açúcar ao óxido de cálcio sobre parâmetros digestivos e o desempenho de novilhas Nelore. Revista Brasileira de Zootecnia, v.40, p.648-656, 2011.

PONTES, R.A.M. Cana de açúcar “in natura” ou ensilada com oxido de cálcio e uréia em dietas de ovinos. 2007. 
54f. Dissertação (Mestrado em Zootecnia) - Universidade Federal de Viçosa, Viçosa, MG.

PRESTON, R.L.; SCHNAKENBERG, D.D.; PFANDER, W.H. Protein utilization in ruminants. I. Blood urea nitrogen as affected by protein intake. Journal of Nutrition, v.68, p.281-288, 1965.

RUSSEL, J.B.; WILSON, D.B. Why are ruminal cellulolytic bactéria unable to digest cellulose at low pH? Journal of Dairy Science, v.79, p.1503-1509, 1996.

SAMPAIO, C.B. Consumo, digestibilidade e dinâmica ruminal em bovinos alimentados com forragem tropical de baixa qualidade suplementados com compostos nitrogenados. 2007. 80f. Dissertação (Mestrado em Zootecnia) - Universidade Federal de Viçosa, Viçosa, MG.

SAMPAIO, C.B.; DETMANN, E.; LAZZARINI, I. et al. Rúmen dynamics of neutral detergent fiber en cattle fed low-quality tropical forage and supplemented with nitrogenous compounds. Revista Brasileira de Zootecnia, v.38, n.3, p.560-569, 2009.

SILVA, D.J.; QUEIROZ, A.C. Análise de alimentos (Métodos químicos e biológicos). 3.ed. Viçosa, MG: Editora UFV, 2002. 235p.

SILVEIRA, R.N.; BERCHIELLI, T.T.; CANESIN, R.C. et al. Influência de fontes de nitrogênio no consumo e digestibilidade aparente total e parcial de novilhos alimentados com cana-de-açúcar. Acta Scientiarum Animal Sciences, v.31, n.3, p.279-285, 2009. STATISTICAL ANALYSIS SYSTEM - SAS. User's guide. Version 8. Cary, 2000. (CD-ROM).

USHIDA, K.; LASSALAS, B.; JOUANY, J.P. Determination of assay parameters for RNA analysis in bacterial and duodenal samples by spectrophotometry. Influence of sample treatment and preservation. Reproduction and Nutrition Development, v.25, n.6, p.1037-1046, 1985.

VALADARES, R.F.D.; GONÇALVES, L.C.; RODRIGUEZ, N.M. et al. Proteína em dietas de bovinos. 4. Concentrações de amônia ruminal e uréia plasmática e excreções de uréia e creatinina. Revista Brasileira de Zootecnia, v.26, n.6, p.1270-1278, 1997.

VALADARES FILHO, S.C.; RODRIGUES PAULINO, P.V.; MAGALHÃES, K.A. Exigências nutricionais de zebuinos e tabelas de composição de alimentos BR-CORTE. Viçosa, MG: Universidade Federal de Viçosa, Departamento de Zootecnia, 2006. 142p.

VAN SOEST, P.J.; ROBERTSON, J.B. Analysis of forages and fibrous foods. Ithaca: Cornell University, 1985. 202p. 